\title{
The Fiscal Theory of the Price Level and the Interaction of Monetary and Fiscal Policies: The Brazilian Case ${ }^{*}$
}

Tito Belchior S. Moreira**

Geraldo da Silva e Souza**

Charles Lima de Almeida ${ }^{* * * *}$

\begin{abstract}
This paper aims to derive an optimal monetary policy rule in a context of fiscal disequilibrium and to empirically test whether Brazil presents active or passive fiscal and monetary policies. We analyze the transmission channels of the fiscal and monetary policies through estimation of a Philips curve and the fiscal IS curve. The results indicate that the fiscal deficit is statistically significant and affects the inflation rate indirectly via output gap. The empirical findings using the Leeper model indicate that the monetary policy is passive whereas the fiscal policy is active. In this context, we found empirical evidence that the Brazilian economy shows a fiscal dominance regime for the period 1995:
\end{abstract} I to 2006: II.

Keywords: Active and Passive Policies, Fiscal Dominance Regime, Fiscal Theory of the Price Level, Optimal Monetary Rule.

JEL Codes: E52, E61, E63.

\footnotetext{
${ }^{*}$ Submitted in March 2006. Revised in April 2007. We thank the helpful comments of Adolfo Sachsida, Marco A. Bittencourt and anonymous referees.

** Universidade Católica de Brasília - UCB, SGAN 916, Módulo B, Brasília - DF, CEP: 70.790160, Brasil. E-mail: tito@pos.ucb.br and tito@pesquisador.cnpq.br

${ }^{* * *}$ Universidade de Brasília.

${ }^{* * * *}$ Tribunal de Contas da União.
}

Brazilian Review of Econometrics v. $27, \mathrm{n}^{\circ} 1$, pp. $85-106$ May 2007 


\section{Introduction}

Countries that currently adopt the inflation targeting regime, such as the United Kingdom, Canada, and New Zealand, do not face severe fiscal disequilibrium. However, many of the emerging countries have adopted the inflation targeting regime in a context of fiscal disequilibrium. Brazil, in spite of the successive primary surplus achieved in the past few years, still presents a high nominal deficit and a worrisome public debt.

The high interest rates used by the Central Bank of Brazil as a means to reach the inflation target have contributed towards increasing the debt service. The ongoing growth of the nominal deficit and, consequently, of the public debt, makes the fiscal disequilibrium particularly worrisome in a context of a high debt stock and short term liabilities. In addition, many of the debt bonds are indexed by the interest rate (SELIC) with the aggravation that Brazil has the highest real interest rate in the world.

The context of fiscal disequilibrium mentioned above induces many economists to believe that the Central Bank of Brazil (BACEN) should take into account fiscal variables in its monetary policy rule. Morais and Andrade (2004), for instance, evaluate an optimal rule of monetary policy assuming that the monetary authority follows a flexible inflation targeting regime according to which there is the possibility of including also a target for the debt/GDP ratio. In this model, the public debt affects the risk premium directly and, consequently, the exchange rate as well.

Other Brazilian economists have been concerned with the issue of fiscal dominance and have proposed alternative ways to construct monetary rules, which take into consideration the fiscal constraints in the Brazilian case. Most of them impose a fiscal IS $^{1}$ curve which implies an optimal rule of the interest rate reaction also dependent upon the fiscal variable.

Freitas and Muinhos (2002) estimate the Philips and IS equations for Brazil, after the Real Plan, ${ }^{2}$ to study the monetary policy transmission mechanism. The authors work with a fiscal IS in which the output gap depends on the real interest rate, the lagged output gap, the exchange rate and the fiscal deficit.

Verdini (2003) develops a model with the purpose of assessing whether the monetary rules, derived under the inflation targeting regime, can be adapted to correct significant changes of the public debt. The results indicate that, despite the potential long-run solvency, the debt profile generates concerns in the short run.

\footnotetext{
${ }^{1}$ Typically, in the literature, the IS and Phillips curves are used to obtain an optimal monetary rule. In this context, the denomination "fiscal IS" is justified since a fiscal variable (fiscal deficit) appears in the defining equation.

${ }^{2}$ In 1994, the Brazilian government implemented a price stabilization program known as Real Plan.
} 
Loyo (1999) adopts the fiscalist approach to price determination. His motivation is the Brazilian experience in the late 1970s and early 1980s. He proposes a model that is suitable to deal with hyperinflation in which most of the fiscal action concentrates on the interest bill on public debt and debt rollover, rather than on primary budget deficits or seigniorage. According to his own words "Higher interest rates cause the outside financial wealth of private agents to grow faster in nominal terms, which in fiscalist models calls for higher inflation. If the monetary authority responds to higher inflation with sufficiently higher nominal interest rates, a vicious circle is formed."

Fialho and Portugal (2005) examine the predominance of a monetary or fiscal dominance regime in Brazil in the post Real Plan period. They argue that the macroeconomic coordination between monetary and fiscal policies in Brazil was virtually a substitute and predominantly monetary policy during the period.

Blanchard (2004) considers the efficacy of the Brazilian monetary policy in 2002 and 2003. He points to the perverse effects of the monetary policy undertaken by the Central Bank with the pursue of the inflation targeting regime in an environment of fiscal dominance.

Benigno and Woodford (2006) analyze an optimal monetary policy by taking into account the consequences of the monetary policy for the government budget. They assume a fiscal regime and distorting taxes. The authors argue that some countries which adopt the inflation targeting regime have substantial difficulties controlling fiscal imbalances, so the additional strains resulting from strict control of inflation are of substantial concern. In this sense, Sims (2005) has notably argued that inflation targeting can be counterproductive under some fiscal regimes.

The argument that the Brazilian fiscal policy affects the monetary policy seems to be sound, and some economists share this perception. Thus, the inclusion of the fiscal policy variables in the Central Bank's optimal monetary rule apparently makes sense. However, as mentioned by a referee, a fiscal variable can affect the inflation rate indirectly via output gap. This does not mean that the monetary policy must react directly to the fiscal variable. A good analogy is the impact of the exchange rate on inflation. Most of central banks adopting the targeting inflation regime make use of a monetary policy that does not react directly to changes in the exchange rate. In fact, the reaction is indirect via inflationary impact. In other words, the traditional Taylor rule states that the central bank should react just to the inflation rate and to the output gap, independently from the origin of change in these variables. 
Although the central banks do not necessarily include explicitly fiscal variables or the exchange rate in their reaction function (Taylor rule), this procedure is very useful to policymakers. They may assess the significance of these variables and whether or not they affect the inflation rate. If the fiscal variable is significant, for example, it means that it affects the inflation rate via output gap. In this sense, the fiscal policy affects the inflation rate. This suggests that fiscal policy also acts by determining price levels.

Typically, optimal monetary policy models assume that the fiscal policy is given and does not depend on current and future monetary policies. This implies that the fiscal authority chooses a tax rate in such a way that the public debt will be solvent. ${ }^{3}$ Therefore, the Ricardian equivalence hypothesis is valid and the monetary policy is active ${ }^{4}$ and the fiscal policy is passive. Hence, if an economy supports the Ricardian equivalence hypothesis, it does not make sense to use a fiscal variable in the IS equation. Of course, this may not be the case in countries presenting serious fiscal imbalances.

The Brazilian economy shows fiscal disequilibrium. If we assume that the monetary rule takes into account fiscal restrictions, we will admit, implicitly, a passive monetary policy and/or an active fiscal policy. The fiscal policy would restrict the efficacy of the monetary policy. Thus, it is of importance to test empirically whether or not the fiscal and monetary policies are passive. This information is necessary before proposing an optimal rule of monetary policy with the inclusion of fiscal variables.

The main purpose of this paper is to derive, for Brazil, an optimal monetary policy rule in face of fiscal disequilibrium, and to test empirically whether or not the monetary and fiscal policies are passive in the period 1995 to 2006 . We intend to analyze the impacts of monetary and fiscal policies on the inflation rate and on the interest rate in several alternative ways:

1. Through the transmission channels of the fiscal and monetary policies, by estimating the Phillips curve and a fiscal IS. Here we assess whether or not the fiscal variable is significant and how it affects the inflation rate.

2. Evaluating the interest rate response to changes in the inflation rate, output gap, fiscal deficit and exchange rate based on an optimal monetary policy rule a la Taylor (1993).

3. Fitting the Leeper model $(1991,2005)$ and testing whether or not the monetary and fiscal policies are passive.

\footnotetext{
${ }^{3}$ The fiscal policy is passive.

${ }^{4} \mathrm{~A}$ monetary policy is active when the fiscal policy does not impose restrictions on the monetary policy and the latter is concerned only with the inflation target. Therefore, there is no concern from the monetary authority with the public debt, since the economic regime is Ricardian.
} 
Our discussion proceeds as follows. Section 2 shows a brief discussion on the fiscal theory of the price level (FTPL), and the active and passive monetary and fiscal policies. In Section 3, we derive an optimal monetary policy rule model by assuming a fiscal IS curve. In Section 4, we present empirical findings related to the joint fit of the fiscal IS and Phillips curves. Section 5 presents the empirical optimal monetary policy rule. In Section 6, we introduce the Leeper model (1991, 2005). In Section 7, we show the empirical consequences of the Leeper model. In Section 8, we comment briefly on the empirical results of the validation of the Ricardian regime for the Brazilian economy. Finally, in Section 9, we present a summary and the final remarks on our findings.

\section{Monetary and Fiscal Policies: A Brief Discussion}

Since the 1970s, Brazil has systematically shown internal and/or external macroeconomic disequilibrium. This condition generated substantial inflation. To attenuate this effect, policymakers resorted to stabilization policies. These policies frequently result in internal and/or external debt disequilibrium. One of the possible explanations to the debt stock disequilibrium is the possible inconsistencies between fiscal and monetary policies.

The debate between monetary and fiscal policies has been restricted to the discussion between rules versus discretionary behavior. Nowadays, this discussion has mainly emphasized the inflation targeting proposals. The optimal monetary policy rule assumes that the fiscal policy is not relevant to the monetary policy. It is assumed implicitly that public debt is solvent. In other words, the fiscal authorities always adjust the taxes in order to guarantee debt solvency. In fact, in a fiduciary regime, the debt will always be solvent given that it is possible to use the seigniorage as source of revenue. With the fiscal policy neglected, the discussion about coordination between monetary and fiscal policies is weakened. In this context, some researchers place emphasis on the discussion related to the coordination between monetary and fiscal policies to keep economic stability. Sargent and Wallace (1981), for example, discuss this question in their seminal work related to the unpleasant monetarist arithmetic.

Sargent and Wallace (1981) show that if the monetary policy affects the extent to which the seigniorage is exploited as a source of revenue, then the monetary and fiscal policies should be coordinated. In this sense, the price stabilization policy depends on the following question: Who acts first, the fiscal or the monetary authority? Or, who imposes discipline on whom? The unpleasant monetarist arithmetic suggested by the authors appears in a process of policy coordination in which the fiscal policy dominates monetary policy and the monetary authority confronts itself with restrictions imposed by the demand of government bonds. This is a possible case of active fiscal policy and passive monetary behavior.

Many papers show the equilibrium policy as the result of a game between fiscal and monetary authorities. Sargent (1986), for example, makes the description of 
a Ricardian regime in which the monetary authority is the dominant player while the fiscal authority is the follower. In this sense, the fiscal authority increases the fiscal tax to satisfy the condition of budget equilibrium. This is an example of a passive fiscal policy and active monetary policy.

According to Leeper (1991), what distinguishes an active policy from a passive one is the fact that the active policy takes into account the expected future while the passive one relies on the behavior of current and past values of economic variables. Thus, an active policy is not restricted by current conditions and may well include a choice of a decision rule that depends on past, current or future values of economic variables.

A passive policy or passive authority (fiscal or monetary), on the one hand, is restricted by decisions of consumer optimization and by the actions of the active authority, on the other hand. If the fiscal policy is passive, for example, the decision rule of the fiscal authority will necessarily depend on the public debt, current and/or past.

Blanchard (2004) emphasizes that the discussion related to fiscal dominance is not new. It appeared for the first time in the literature in the works by Martins (1980) and Sargent and Wallace (1981). Martins (1980), in his seminal paper on the FTPL, states that the price of bonds is analogous to the price level, and the nominal rate of interest is determined by the bond/money ratio and bears no close relationship to the rate of expansion of the price level. The recent developments were started anew with the FTPL of Woodford (2003). ${ }^{5}$ The studies of Leeper (1991), Sims (1994), Woodford (1994, 1995, 1997, 2001), and Cochrane (1998, $2001 \mathrm{a}, \mathrm{b})$ all concentrate on the discussion about coordination and interaction between the monetary and fiscal policies.

The main point emphasized by the research on the FTPL is that the intertemporal government budget constraint and the fiscal policy are the determining factors for the price level. This argument runs counter to the traditional theory of price determination, in which the stock of money and the monetary authority are the only determinant of the price level. Moreover the fiscal policy, explicitly or implicitly, passively adjusts the primary surplus to guarantee government solvency for any price level. ${ }^{6}$ Since the fiscal authority is free to choose the primary surplus, independently of the government debt, then it is the price level that has to adjust itself to satisfy the intertemporal government budget constraint in a way that there is only one price level compatible with the equilibrium.

The FTPL can be understood, in a simplistic way, as an application of one of the aspects discussed by Sargent and Wallace (1981), where the fiscal policy imposes restrictions on the extent of results from the monetary policy.

The main distinction between the classic theory and FTPL lies in the interpretation of the intertemporal government budget. According to the monetarist

\footnotetext{
${ }^{5}$ See Loyo (1999) and Sala (2004) for applications of Woodford's theory.

${ }^{6}$ This regime is denominated Ricardian price determination by Woodford (1995).
} 
tradition, the government intertemporal equation is a constraint that is assured for any price level. According to the FTPL, the government intertemporal equation is an equilibrium condition determining the equilibrium price level.

The distinction between Ricardian and non-Ricardian regimes brings important implications to economic policies. Based on the Ricardian regime, a good monetary policy is a necessary and sufficient condition to guarantee low inflation. An independent central bank, with a strong institutional commitment towards price stability, should compel the fiscal authority to adopt a responsible and appropriate fiscal policy. For the non-Ricardian regime, a good monetary policy is not a sufficient condition to ensure low inflation, unless additional measures are taken into consideration to restrict the freedom of the fiscal authority.

\section{An Optimal Monetary Policy Rule Model}

Consider the traditional IS curve

$$
y_{t+1}=a_{1} y_{t}+a_{2} y_{t-1}+a_{3}\left(R_{t}-E_{t} \pi_{t+1}\right)+a_{4} f d_{t}+a_{5} e_{t}+u_{t+1}
$$

where $y_{t}$ denotes the output gap, ${ }^{7} R_{t}$ is the nominal interest rate, ${ }^{8} \pi_{t}$ is the inflation rate, $f d_{t}$ is the fiscal deficit (government expenditures minus government revenues), $e_{t}$ is the real exchange rate, and $u_{t}$ is a demand shock, assumed to be normally distributed. ${ }^{9}$

The supply curve (AS curve) is represented by the following Phillips curve

$$
\pi_{t+1}=a_{6} \pi_{t}+a_{7} y_{t}+a_{8} \Delta q_{t}+\eta_{t+1}
$$

and the equation for the nominal exchange rate $q_{t}$ is the random walk

$$
q_{t+1}=q_{t}+\vartheta_{t+1}
$$

The pass-through effect is $\Delta q_{t}=q_{t}-q_{t-1}$. We assume that the shocks $\eta_{t}, u_{t}$ and $\vartheta_{t}$ have zero mean and are uncorrelated.

The expected signs for the parameters are $a_{1}>0, a_{2}>0, a_{3}<0, a_{4}>0$, $a_{5}>0, a_{6}>0, a_{7}>0$ and $a_{8}>0$.

By taking expectations in Equation (2),

$$
E_{t} \pi_{t+1}=a_{6} \pi_{t}+a_{7} y_{t}
$$

and plugging this expression into (1), we obtain

$$
y_{t+1}=\alpha_{1} y_{t}+a_{2} y_{t-1}+a_{3}\left(R_{t}-a_{6} \pi_{t}\right)+a_{4} f d_{t}+a_{5} e_{t}+\kappa_{t+1}
$$

\footnotetext{
${ }^{7}$ We define the output gap as the difference between the real current output and the potential output.

${ }^{8}$ We are assuming Fisher's equation, $R_{t}=r_{t}+E_{t} \pi_{t+1}$, where $r$ is the real interest rate.

${ }^{9}$ This model follows the approach of Charles et al. (2003), which is similar to that of Walsh (2003:508-511).
} 
where $\alpha_{1}=a_{1}-a_{3} a_{7}$.

Policy actions, via control of $R_{t}$, affect output and inflation with a one-period lag. At time $t$, the choice of $R_{t}$ affects $y_{t+1}$ and $\pi_{t+1}$, but $y_{t}, y_{t-1}, \pi_{t}, f d_{t}, e_{t}$ and $q_{t}$ are predetermined. The state variable at instant $t$ is

$$
z_{t}=a_{6} \pi_{t}+a_{7} y_{t}+a_{8} \Delta q_{t}
$$

We define

$$
\theta_{t}=\alpha_{1} y_{t}+a_{2} y_{t-1}+a_{3}\left(R_{t}-a_{6} \pi_{t}\right)+a_{4} f d_{t}+a_{5} e_{t}
$$

Equations (2) and (5) can be rewritten as

$$
\pi_{t+1}=z_{t}+\eta_{t+1}
$$

and

$$
y_{t+1}=\theta_{t}+u_{t+1}
$$

We assume that the central bank's loss function is given by

$$
L=\frac{1}{2} E_{t} \sum_{t=1}^{\infty} \beta^{i}\left[\lambda y_{t+i}^{2}+\pi_{t+i}^{2}\right]
$$

By taking the expression (6) one-step forward and substituting (8) and (9) into (6), we have

$$
z_{t+1}=a_{6} z_{t}+a_{7} \theta_{t}+a_{8} \Delta q_{t+1}+a_{6} \eta_{t+1}+a_{7} u_{t+1}
$$

The policymaker objective is to minimize the loss function (10) subject to (11). Hence, we can define the value function as

$$
V\left(z_{t}\right)=\min _{\theta_{t}} E_{t}\left[\frac{1}{2}\left(\lambda y_{t+1}^{2}+\pi_{t+1}^{2}\right)+\beta V\left(z_{t+1}\right)\right]
$$

By substituting (8), (9) and (11) into (12), we get

$$
\begin{aligned}
V\left(z_{t}\right) & =\min _{\theta_{t}}\left[\frac{1}{2} \lambda E_{t}\left(\theta_{t}+u_{t+1}\right)^{2}+\frac{1}{2} E_{t}\left(z_{t}+\eta_{t+1}\right)^{2}+\beta E_{t} V\left(a_{6} z_{t}+a_{7} \theta_{t}\right.\right. \\
& \left.\left.+a_{8} \Delta q_{t+1}+a_{7} u_{t+1}+a_{6} \eta_{t+1}\right)\right]
\end{aligned}
$$

The first-order condition for (13) is

$$
\lambda \theta_{t}+a_{7} \beta E_{t} V_{\theta_{t}}\left(z_{t+1}\right)=0
$$

By the Envelope Theorem $V_{\theta}=V_{z}$, we have 


$$
V_{z}\left(z_{t}\right)=z_{t}+a_{6} \beta E_{t} V_{\theta}\left(z_{t+1}\right)
$$

By multiplying (15) by $a_{7} / a_{6}$, substituting in (14), and taking expectations relative to the one-step ahead equation, one obtains

$$
E_{t} V_{\theta}\left(z_{t+1}\right)=a_{6} z_{t}+a_{7} \theta_{t}-\frac{a_{6} \lambda}{a_{7}} E_{t}\left(\theta_{t+1}\right)
$$

By inserting (16) into (14), we get

$$
\theta_{t}=-\frac{a_{6} a_{7} \beta}{\lambda+a_{7}^{2} \beta} z_{t}+\frac{a_{6} \beta \lambda}{\lambda+a_{7}^{2} \beta} E_{t}\left(\theta_{t+1}\right)
$$

When the policy is established at instant $t, z_{t}$ is the state variable, and we will look for policy rules of the form $\theta_{t}=X z_{t}$, where $X$ is to be determined. ${ }^{10}$ Since

$$
E_{t}\left(\theta_{t+1}\right)=X E_{t}\left(z_{t+1}\right)=X\left(a_{6}+a_{7} X\right) z_{t}
$$

we see that $X$ is the solution to the second-degree equation

$$
\lambda \beta a_{6} a_{7} X^{2}+\left(-\lambda+\beta a_{6}^{2} \lambda-a_{7}^{2} \beta\right) X-a_{6} a_{7} \beta=0
$$

It follows that

$$
X=\frac{\left(\lambda-\beta a_{6}^{2} \lambda+a_{7}^{2} \beta\right) \pm \sqrt{\left(-\lambda+\beta a_{6}^{2} \lambda-a_{7}^{2} \beta\right)^{2}+4\left(a_{6}^{2} a_{7}^{2} \beta^{2} \lambda\right)}}{2 \beta a_{6} a_{7} \lambda}
$$

After some algebra, we see that the product of the roots $\left(X_{1}\right.$ and $\left.X_{2}\right)$ is

$$
X_{1} X_{2}=-\frac{1}{\lambda}<0
$$

and therefore the roots have opposite signs. Any root satisfying the stability condition may be used. $^{11}$ to define the optimal rule. In our empirical exercise only the negative root $\pi_{2}$ (say) satisfies this condition. Substituting the negative root in (20) into $\theta_{t}=X_{2} z_{t}$ leads to

$$
\theta_{t}=\frac{\left(\lambda-\beta a_{6}^{2} \lambda+a_{7}^{2} \beta\right)-\sqrt{\left(-\lambda+\beta a_{6}^{2} \lambda-a_{7}^{2} \beta\right)^{2}+4\left(a_{6}^{2} a_{7}^{2} \beta^{2} \lambda\right)}}{2 \beta a_{6} a_{7} \lambda} z_{t}
$$

By inserting the $(6)$ and (7) into $\theta_{t}=X_{2} z_{t}$, we derive the following optimal rule for the nominal interest rate,

\footnotetext{
${ }^{10}$ See Walsh (2003:508-511).

${ }^{11}$ Since $z_{t+1}=a_{6} z_{t}+a_{7} \theta_{t}+a_{8} \Delta q_{t+1}+a_{6} \eta_{t+1}+a_{7} u_{t+1}$ and $\theta_{t}=X z_{t}$ then $z_{t+1}=a_{6} z_{t}+$ $a_{7} X z_{t}+a_{8} \Delta q_{t+1}+a_{6} \eta_{t+1}+a_{7} u_{t+1}=\left(a_{6}+a_{7} X\right) z_{t}+a_{8} \Delta q_{t+1}+a_{6} \eta_{t+1}+a_{7} u_{t+1}$. The stability of the inflation process requires $\left|a_{6}+a_{7} X\right|<1$.
} 


$$
R_{t}=\frac{a_{7} X_{2}-\alpha_{1}}{a_{3}} y_{t}-\frac{a_{2}}{a_{3}} y_{t-1}+\frac{a_{6} X_{2}+a_{3} a_{6}}{a_{3}} \pi_{t}-\frac{a_{4}}{a_{3}} f d_{t}-\frac{a_{5}}{a_{3}} e_{t}+\frac{a_{8} X_{2}}{a_{3}} \Delta q_{t}
$$

We note that

$$
\frac{\partial R_{t}}{\partial y_{t}}>0 ; \frac{\partial R_{t}}{\partial y_{t-1}}>0 ; \frac{\partial R_{t}}{\partial_{\pi_{t}}}>0 ; \frac{\partial R_{t}}{\partial f d_{t}}>0 ; \frac{\partial R_{t}}{\partial e_{t}}>0 ; \frac{\partial R_{t}}{\partial \Delta q_{t}}
$$

The monetary policy rule (23) calls for changes in the nominal interest rate in response to changes in the output gap, inflation rate, nominal deficit, real exchange rate and changes in the nominal exchange rate. Any increase in one of these variables leads the policymaker to increase the nominal interest rate. Hence the policymaker can reduce the deviation of the current inflation from the inflation target.

\section{Empirical Results: IS/Phillips Equations}

In our empirical work, we use quarterly data from 1995:1 to 2006:2. All variables are in natural logs. As a proxy for real output gap (y), we compute the difference between GDP and the same GDP series smoothed by the Hodrick-Prescot filter. The inflation rate $(\pi)$ is measured by IPCA, the Brazilian consumer price index used by the Central Bank to target inflation. The nominal interest rate, $(R)$, is SELIC, which is the primary interest rate in Brazil. As suggested by a referee, we consider the nominal fiscal deficit/GDP $(f d / G D P)$ ratio as the relevant fiscal variable. The effective real exchange rate $(e)$ is a proxy for the real exchange rate. Changes in the nominal exchange rate are measured by changes in the effective nominal exchange rate. We use a dummy variable $(D)$ to capture the effect of the period 1995-1998 in which the exchange rate was administered. The source of data is the Brazilian Central Bank.

Table 1 shows a unit root test including a constant for variables in level and no constant otherwise. The tests reject the unit root hypothesis for $f d / G D P$, $\Delta$ real exchange rate, $\Delta$ nominal exchange rate, output gap, inflation rate and the nominal interest rate at the $5 \%$ level. Further inspections of the correlograms of these series suggest stationarity. 
Table 1

Unit root tests

\begin{tabular}{ccccc}
\hline Variables & $\begin{array}{c}\text { ADF } \\
\text { test }\end{array}$ & $\begin{array}{c}0.05 \\
\text { critical } \\
\text { value }\end{array}$ & $\begin{array}{c}\text { Phillips } \\
\text { Perron } \\
\text { test }\end{array}$ & $\begin{array}{c}0.05 \text { critical } \\
\text { value }\end{array}$ \\
\hline $\begin{array}{c}\text { Nominal fiscal } \\
\text { deficit/GDP }\end{array}$ & -5.784 & -2.928 & -5.759 & -2.928 \\
\hline $\begin{array}{c}\triangle \text { Real } \\
\text { exchange rate }\end{array}$ & -5.899 & -2.930 & -5.864 & -2.930 \\
\hline $\begin{array}{c}\triangle \text { Nominal } \\
\text { exchange rate }\end{array}$ & -5.321 & -2.928 & -5.346 & -2.928 \\
\hline Output gap & -4.230 & -2.935 & -8.149 & -2.928 \\
\hline Inflation rate & -3.568 & -2.928 & -3.337 & -2.928 \\
\hline $\begin{array}{c}\text { Nominal } \\
\text { interest rate }\end{array}$ & -3.712 & -2.931 & -3.219 & -2.928 \\
\hline
\end{tabular}

Since the inflation rate is a stationary process, its expected value is constant through time. Thus, $E_{t} \pi_{t+1}=\bar{\omega}$. By substituting this expression into (1), the IS equation becomes

$$
y_{t}=a_{1} y_{t-1}+a_{2} y_{t-2}+a_{3} R_{t-1}-a_{3} \varpi+a_{4} f d_{t-1}+a_{5} e_{t-1}+u_{t}
$$

By adding the dummy variable, the equation is

$$
y_{t}=c_{0}+c_{1} D_{t-1}+a_{1} y_{t-1}+a_{2} y_{t-2}+a_{3} R_{t-1}+a_{4} f d_{t-1}+a_{5} \Delta e_{t-1}+u_{t}
$$

where $c_{0}=-a_{3} \bar{\omega}$. We use $\Delta e$ in (24) since $e$ may not be stationary. We follow Freitas and Muinhos (2002). They use $\Delta e$ in the specification of the IS curve.

The Phillips curve is

$$
\pi_{t}=c_{2}+c_{3} D_{t-1}+a_{6} \pi_{t-1}+a_{7} y_{t-1}+a_{8} \Delta q_{t-1}+\eta_{t}
$$

This system defined by Equations (24) and (25) is estimated by two-stage least squares. We use GMM to correct the standard errors. As suggested by a referee, we use the nominal interest rate instead of the real interest rate to obtain the Taylor rule. Tables 2 and 3 show the parameter estimates of Equations (24) and (25), respectively. 
Table 2

Results of the estimation - 2SLS with GMM standard errors:

$$
y_{t}=c_{0}+c_{1} D_{t-1}+a_{1} y_{t-1}+a_{2} y_{t-2}+a_{3} R_{t-1}+a_{4} f d_{t-1}+a_{5} \Delta e_{t-1}+u_{t}
$$

\begin{tabular}{cccc}
\hline Variables & Coefficient & $t$-Statistic & $p$-value \\
\hline Constant & 0.057 & 12.856 & $<0.0001$ \\
\hline Dummy & $-1.84^{*} 10^{-8}$ & -13.299 & $<0.0001$ \\
\hline Output gap (-1) & 0.125 & 3.972 & 0.0002 \\
\hline Output gap (-2) & -0.107 & -5.229 & $<0.0001$ \\
\hline Nominal interest rate (-1) & -2.649 & -11.479 & $<0.0001$ \\
\hline (Nominal fiscal deficit /GDP) $(-1)$ & 0.016 & 2.066 & $<0.0427$ \\
\hline$\Delta$ (Real exchange rate) (-1) & 0.024 & 3.163 & 0.0023 \\
\hline$R^{2}$ & 0.492 & & \\
\hline Instruments: $\left|a_{6}+a_{7} X\right|<1(-1$ to -4$), X(-1$ to -5$), \Delta e(-1$ to -4$), \Delta q(-5)$,
\end{tabular}

Instruments: $\left|a_{6}+a_{7} X\right|<1(-1$ to -4$), X(-1$ to -5$), \Delta e(-1$ to -4$), \Delta q(-5)$, $\pi(-1$ to -4$)$, D1, Constant.

Table 3

Results of the estimation - 2SLS with GMM standard errors:

$$
\pi_{t}=c_{2}+c_{3} D_{t-1}+a_{6} \pi_{t-1}+a_{7} y_{t-1}+a_{8} \Delta q_{t-1}+\eta_{t}
$$

\begin{tabular}{cccc}
\hline Variables & Coefficient & $t$-Statistic & $p$-value \\
\hline Constant & 0.002 & 8.527 & $<0.0001$ \\
\hline Dummy & $2.80^{*} 10^{-9}$ & 15.702 & $<0.0001$ \\
\hline Output gap (-1) & 0.016 & 2.669 & 0.0095 \\
\hline Change in nominal & 0.032 & 12.797 & $<0.0001$ \\
\hline exchange rate (-1) & & \\
\hline Inflation rate $(-1)$ & 0.245 & 9.190 & $<0.0001$ \\
\hline \multicolumn{4}{c}{$R^{2}$} \\
\hline $\begin{array}{l}\text { Instruments: } f d / G D P(-1 \text { to }-4), y(-1 \text { to }-5), \Delta e(-1 \text { to }-4), \Delta q(-5), \\
\pi(-1 \text { to }-4), \text { D1, Constant. }\end{array}$
\end{tabular}

The $J$-statistic is 0.287 with a $p$-value of 0.176 and there is no evidence to reject the model specification.

All parameters in (24) and (25) are highly significant. All estimates show the expected signs with the exception of output gap (-2). Indeed, the output gap lags in Equation (24) show opposite signs. Carneiro and $\mathrm{Wu}$ (2002) point out that this contrast is necessary to control the seasonality pattern of inertia and dynamics strongly present in time series of the output. The positive parameter for the change in the real exchange rate implies domestic currency depreciation.

The effect of interest rate on inflation is indirect. A quarterly $1 \%$ increase in nominal interest rate will negatively affect the output gap in $2.649 \%$. Given that a $1 \%$ decrease in output gap reduces inflation by $0.016 \%$, the final effect of a $1 \%$ increase in the interest rate will cause a $0.042 \%$ quarterly decrease in the inflation rate.

The effect of fiscal deficit on inflation is also indirect. A $1 \%$ quarterly decrease in the nominal deficit/GDP ratio will decrease output gap by $0.016 \%$. A $1 \%$ decrease in output gap reduces inflation by $0.016 \%$. The final effect of a $1 \%$ 
decrease in fiscal deficit will be a reduction of $0.0003 \%$ in the inflation rate. The effect does not seem to be of economic importance, but it is statistically significant.

\section{The Optimal Rule}

We assume $\beta=0.98$ and $\lambda=1$ in the derivation of the optimal rule. These parameters are the intertemporal discount factor and the relative weight of output gap in the loss function, respectively. Substituting the values for $\beta$ and $\lambda$ and the parameter estimates shown in Tables 2 and 3 into (23) leads to

$$
R_{t}=0.063 y_{t}-0.040 y_{t-1}+0.245 \pi_{t}+0.006 f d_{t}+0.009 \Delta e_{t}+0.00005 \Delta q_{t}
$$

where $X_{2}=-0.004$. According to the optimal rule, the nominal interest rate increases less than $1 \%$ for each $1 \%$ increase for any given $1 \%$ relative change in any of the right-hand side variables in (26), ceteris paribus.

The optimal rule policy ensures a nominal interest rate that will act to lower inflation. We note that the nominal interest rate reacts strongly to the inflation rate and that the reaction to the change in nominal exchange rate is inexpressive. The reaction of the nominal interest rate to changes in fiscal deficit suggests that the monetary policy is not active and/or that the fiscal policy is active.

Another important issue in the context of the theoretical model of Section 3 is that the stability condition $\left|a_{6}+a_{7} X_{2}\right|=0.2449<1$ holds.

For $\beta=0.98$ and the estimates of (24) and (25), Figure 1 depicts inflation as a function of $\lambda$. The latter is the relative weight of output fluctuations in the loss function. We see that the higher the relative weight on output fluctuations in the loss function, the lower will be the changes required in the nominal interest rate in response to changes in the inflation rate.

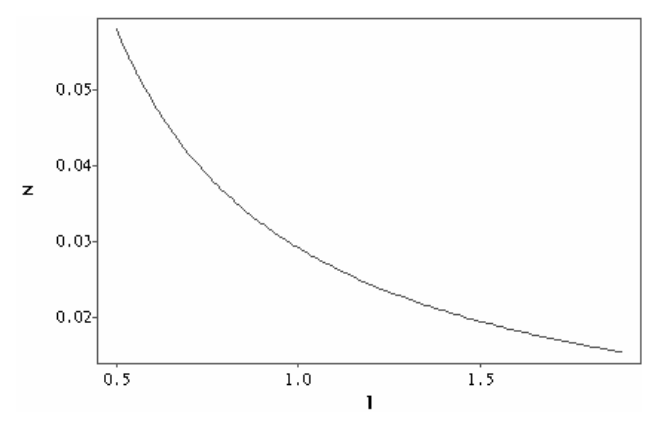

Figure 1

Inflation coefficient in the nominal interest rate rule $v s$ weight (l) of output changes 
Economic policy affects the volatility of output and inflation. As pointed out by Walsh (2003), the policymaker seeks to "minimize the variance of inflation for each variance of output around the natural rate. This then provides an efficiency frontier that shows the feasible set of output and inflation variances that can be achieved". The frontier referred to by Walsh (2003) is given in Figure 1.

\section{The Leeper Model}

The model developed by Leeper $(1991,2005)$ defines the conditions according to which the monetary and fiscal policies may be classified as passive and/or active. Using Sidrausky (1967) model, Leeper (1991, 2005) assumes output and government consumption constants. If government consumption is zero, the agent chooses the sequence $\left(c_{t}, M_{t}, B_{t}\right)$ to solve

$$
\max E_{0} \sum_{t=0}^{\infty} \beta^{t}\left[\log \left(c_{t}\right)+\Delta \log \left(M_{t} / p_{t}\right], 0<\beta<1, \Delta>0\right.
$$

subject to

$$
c_{t}+\frac{M_{t}+B_{t}}{p_{t}}+\tau_{t}=y+\frac{M_{t-1}+R_{t-1} B_{t-1}}{p_{t}}
$$

where $M$ is the nominal stock money, $B$ is the government nominal debt, on which a nominal interest rate $R_{t}$ is paid, $c$ is the consumption, $\tau$ is the direct lump-sum tax, and $p$ is the price level.

The budget constraint for this economy, which is also the equilibrium condition of the market goods, is given by

$$
c_{t}=y
$$

where $y$ is the output. The first-order conditions induce the equilibrium relations defining Fisher's equation and demand for money,

$$
\begin{gathered}
\frac{1}{R_{t}}=\beta E_{t}\left[\frac{1}{\pi_{t+1}}\right] \\
m_{t}=\Delta c\left[\frac{R_{t}-1}{R_{t}}\right]^{-1}
\end{gathered}
$$

where $\pi_{t}=p_{t} / p_{t-1}$ and $m_{t}=M_{t} / p_{t}$.

The government policy is the sequence $\left(M_{t}, B_{t}, \tau_{t}\right)$. This sequence satisfies the government budget identity

$$
b_{t}+m_{t}+\tau_{t}=\frac{R_{t-1} b_{t-1}+m_{t-1}}{\pi_{t}}
$$

where $b_{t}=B_{t} / p_{t}$. 
Leeper describes government policies based on simple rules where the fiscal policy is

$$
\tau_{t}=\gamma_{0}+\gamma b_{t-1}+\Psi_{t}
$$

where $\Psi_{t}$ is the exogenous shock, occurring at the beginning of $t$ and following the $\operatorname{AR}(1)$ process

$$
\Psi_{t}=\rho_{\Psi} \Psi_{t-1}+\epsilon_{\Psi t}
$$

with $\left|\rho_{\Psi}\right|<1$ and $E_{t} \epsilon_{\Psi t+1}=0$.

We believe that it makes more sense to consider direct taxes and the nominal government debt relative to GDP. Equation (33) becomes

$$
\frac{\tau_{t}}{G D P_{t}}=\gamma_{0}+\gamma \frac{B_{t-1}}{G D P_{t-1}}+u_{t}
$$

where $u_{t}$ is the stationary $\operatorname{AR}(1)$.

The monetary policy also obeys a simple rule for the interest rate, that is,

$$
R_{t}=\alpha_{o}+\alpha \pi_{t}+\varsigma_{t}
$$

where $\varsigma_{t}$ is an exogenous shock, occurring at the beginning of $t$ and following the $\mathrm{AR}(1)$ process

$$
\varsigma_{t}=\rho_{0} \varsigma_{t-1}+\varepsilon_{\varsigma t}
$$

with $\left|\rho_{0}\right|<1$ and $E_{t} \varepsilon_{\varsigma t+1}=0$.

Leeper's approach reduces the equilibrium solution of his model to a dynamic system in $\left(\pi_{t}, b_{t}\right)$ and finds the roots $\alpha \beta$ and $\beta^{-1}-\gamma$. The stability condition requires one root less than or equal to one in absolute value and another greater than or equal to one. It follows that the equilibrium generates four regions of interest.

Region 1: $|\alpha \beta| \geq 1$ and $\left|\beta^{-1}-\gamma\right|<1$. This is the case of a unique equilibrium. In this region, monetary shocks produce the usual expected monetary paths and the fiscal shocks are irrelevant. The Ricardian equivalence holds. In this case, the monetary policy is active and the fiscal policy is passive. This means that the monetary policy is effective in the determination of the price level and the monetary authority does not need to worry about the budget constraint, since the fiscal authority is able to choose a taxation level in each point in time that makes the debt solvent. Leeper (2005) shows that the inflation of equilibrium is entirely a monetary phenomenon and that the fiscal shocks do not affect inflation or the nominal interest rate. Comparing this case with the context of the system defined by the fiscal IS and the Phillips curve of Section 3, if the fiscal variable is 
significant in the IS equation, one can conclude that the economy is not in Region 1 and that the monetary policy is not active.

This is the ideal region for the policymaker to instate a target of inflationary regime controlling the interest rate. More precisely, the monetary policy does not have any restrictions and can actively pursue price stability by strongly reacting to inflation. The fiscal policy obeys the restrictions imposed by the monetary policy and by the private sector, and, passively, adjusts direct taxes to achieve budget equilibrium.

Region 2: $|\alpha \beta|<1$ and $\left|\beta^{-1}-\gamma\right| \geq 1$. This region also generates a unique equilibrium. Region 2 represents the FTPL, where tax shocks produce inflation and monetary shocks produce non-monetary impacts. Leeper (2005) argues that in this situation, an exogenous fiscal surplus corresponds to the same hypothesis that Sargent and Wallace (1981) maintain about the fiscal policy when they proposed the expression "unpleasant monetarist arithmetic".

Leeper also argues that, in certain conditions, current policy shocks can not generate changes in the expected future taxes and that this is an essential element in the FTPL. In this case, one has a passive monetary policy and an active fiscal policy. Putting it differently, the fiscal authority denies a strong adjustment in direct taxes, preventing the shocks in the deficit from not being completely financed by future taxation. Now the monetary authority obeys the restrictions imposed by the fiscal policy and by the private sector and allows the reaction of the monetary stock to deficit shocks.

Region 3: $|\alpha \beta|<1$ and $\left|\beta^{-1}-\gamma\right|<1$. In this region, the fiscal and monetary authorities act passively, subject to the budget constraint. Without an additional restriction imposed by an authority, there will be many processes of monetary expansion associated with an initial monetary shock, which are consistent with the equilibrium conditions. In this case, there are an infinite number of equilibrium points, which means that the equilibrium is undetermined. This is the price level indetermination of Sargent and Wallace (1975). If $\alpha$ is small, the indeterminacy appears even if the interest rate rule depends (weakly) on inflation. It can be said that monetary policy is ineffective since it is not able to determine the price level. We therefore suggest coordination between the fiscal and monetary policies, which will force the economy to migrate to Region 1.

Region 4: $|\alpha \beta| \geq 1$ and $\left|\beta^{-1}-\gamma\right| \geq 1$. There is no equilibrium in this region unless the exogenous shocks $\epsilon_{\psi_{t}}$ and $\varepsilon_{\varsigma_{t}}$ are perfectly correlated. The monetary and fiscal policies are both active. In this region, the authorities (fiscal and monetary) neglect the budget constraints to determine prices. Two unstable roots are thus generated. There is no process of monetary expansion assuring that consumers will keep government public deficit bonds, unless the policy shocks violate the 
assumption of mutually uncorrelated shocks.

The discussion above implies important consequences for policy-making decisions. The optimal monetary policy rules assume, explicitly or implicitly, that the economy is operating in Region 1.

On the other hand, if we assume that the economy is operating in Region 2, where FTPL dominates, an optimal monetary policy rule defined by the control of the interest rate via Taylor rule does not make sense. In Region 2 , the price level is determined by the fiscal policy, and the monetary policy is ineffective given that it is passive. In a context of a non-Ricardian regime, Blanchard (2004) suggests an optimal fiscal rule to control inflation.

In Regions 3 and 4, coordination between the monetary and fiscal authorities is necessary to force the economy to migrate to Region 1.

\section{Empirical Results of Leeper Model}

For the econometric analysis of Leeper model, we use quarterly data. The sample ranges from 1995:1 to 2006:2. All variables are in natural logs, as before. The public debt $(B)$ is represented by the domestic federal public debt. The direct $\operatorname{tax}(\tau)$ is given by the sum of income and land taxes. The direct tax and the public debt are GDP normalized and deseasonalized by the X12 method. The data come from BACEN and IPEA.

The public debt/GDP $(B / \mathrm{GDP})$ and direct tax/GDP $(\tau / \mathrm{GDP})$ ratios are not stationary at $5 \%$ of significance level. Both are stationary in first differences according Table 4 and by an additional correlogram analysis (not shown).

Table 4

Unit root tests

\begin{tabular}{ccccc}
\hline Variables & $\begin{array}{c}\text { ADF } \\
\text { test }\end{array}$ & $\begin{array}{c}0.05 \\
\text { critical } \\
\text { value }\end{array}$ & $\begin{array}{c}\text { Phillips } \\
\text { Perron } \\
\text { test }\end{array}$ & $\begin{array}{c}0.05 \text { critical } \\
\text { value }\end{array}$ \\
\hline Direct tax/GDP & -0.567 & -2.929 & -2.102 & -2.928 \\
Public debt/GDP & -2.560 & -2.928 & -2.461 & -2.928 \\
$\Delta$ (Direct tax/GDP) & -14.912 & -1.948 & -14.712 & -1.948 \\
$\Delta$ (Public debt/GDP $)$ & -4.876 & -1.948 & -5.063 & -1.948 \\
\hline
\end{tabular}

Table 5 shows the Taylor rule corresponding to (35). We see that $\alpha=0.163$ and $\beta=0.98$ imply $|\alpha \beta|<1$. The value of $\beta$ was taken from Lima and Issler $(2003)$. 
Table 5

$R_{t}=\alpha_{o}+\alpha_{1} D_{t}+\alpha \pi_{t}+\varsigma_{t}$

\begin{tabular}{cccc}
\hline Variables & Coefficient & $t$-Statistic & $p$-value \\
\hline Constant & 1.963 & 10.965 & $<0.0001$ \\
Inflation rate & 0.163 & 2.411 & 0.0206 \\
Dummy & -0.550 & -3.240 & 0.0024 \\
AR(1) & 0.489 & 3.851 & 0.0004 \\
MA(1) & 0.949 & 12.997 & $<0.0000$ \\
$R^{2}$ & 0,870 & & \\
\hline
\end{tabular}

As suggested by a referee, we also estimate (35) by adding the real output gap to the equation. We find $\alpha=0.267( \pm 0.064)$ and there is no change in operating region.

Table (6) indicates that direct tax/GDP and public debt/GDP cointegrate.

Table 6

Johansen's cointegration test of $\tau / G D P$ and $B /$ GDP

No trend

\begin{tabular}{cccc}
\hline $\begin{array}{c}\text { Hypothesized } \\
\text { no. of CE** }\end{array}$ & Eigenvalue & $\begin{array}{c}\text { Trace } \\
\text { statistic }\end{array}$ & $\begin{array}{c}5 \% \\
\text { critical } \\
\text { value }\end{array}$ \\
\hline None* & 0.314 & 22.924 & 19.960 \\
At most 1 & 0.145 & 6.730 & 9.240 \\
Hypothesized & Eigenvalue & $\begin{array}{c}\text { Max-Eigen } \\
\text { statistic }\end{array}$ & $\begin{array}{c}5 \% \\
\text { Critical } \\
\text { No. of CE(s) }\end{array}$ \\
& & 16.194 & value \\
None* & 0.314 & 6.730 & 9.240 \\
At most 1 & 0.145 & \multicolumn{3}{c}{} \\
${ }^{*}$ Denotes rejection of the hypothesis at the $5 \%$ level. \\
$* *$ CE = Cointegrating equating.
\end{tabular}

The long-run elasticity between $\tau / G D P$ and $B / G D P$ is $\gamma=0.010( \pm 0.002)$. The Brazilian economy is therefore operating in Region 2 since $|\alpha \beta|=0.262<1$ and $\left|\beta^{-1}-\gamma\right|=1,010>1$.

\section{A Comparative Analysis}

Loyo (1999) was the first to argue that the FTPL provides an explanation for the high inflation observed in Brazil in the late 1970s and early 1980s.

Tanner and Ramos (2003), for monthly data, examine several questions regarding fiscal sustainability and adjustment in Brazil from 1991 to 2000. They find that before the Real plan (July 1994), the regime appears to be fiscal dominant or non-Ricardian rather than monetary dominant, since the primary surplus did not respond to changes in real government debt. After the Real plan, using several short period analyses, evidence points to a sustainable monetary dominance. However, the authors conclude that this finding does not necessarily preclude an 
independent monetary policy and the credibility of the inflation targeting regime. Their methodology includes unit root tests, Granger causality and impulse response functions.

Rocha and Silva (2004) follow the methodology proposed in Canzonery et al. (2001) for testing the validity of the Ricardian regime for the Brazilian economy with annual data from 1996 to 2000. They use unit root tests and VAR to conclude that the data are consistent with a Ricardian regime. Fialho and Portugal (2005), using monthly data from 1995:1 to 2003:9, also follow Canzonery et al. (2001). They apply the approach of Muscatelli et al. (2002) to investigate the interactions between the monetary and fiscal policies using the Markov-switching vector autoregressive model (Krolzig, 1997). They conclude that the macroeconomic coordination between monetary and fiscal policies in placeplaceBrazil was virtually a substitute policy, with a predominantly monetary regime, in opposition to the non-Ricardian policies of the FTPL.

Gonçalves (2005) uses a simple two-period model in which government's preferences are private information to show that a tough monetary stance may help with bringing inflation expectations to lower levels even if the fiscal side of the economy is not in good shape. A restrictive monetary policy leads to higher debt levels and potentially to higher expected inflation (fiscal dominance effect). But, on the other hand, it also allows a tough-type government to separate itself from a lax-type one in the eyes of the public (signaling effect). A feature of the model is that inflation and inherited debt are not necessarily positively correlated for all levels of debt. The author concludes that the high debt levels of Lula's administration inherited from the FHC's term in office (the so-called "damned heritage") may have helped to signal the markets their degree of inflation aversion.

Our use of Leeper model to test the FTLP is original and represents the main contribution of our article. We have found empirical evidence of a non-Ricardian regime. Furthermore, the significance of the fiscal variable in the IS equation corroborates this finding. The Brazilian economy operates under fiscal dominance from the first quarter of 1995 to the second quarter of 2006.

\section{Conclusions}

This article aimed to assess Brazilian economic policies in a context of fiscal disequilibrium from 1995: I to 2006: II. The empirical evidence is that the fiscal deficit affects the output gap directly and, consequently, affects the inflation rate indirectly. The optimal monetary rule calls for changes in the nominal interest rate in response to changes in the fiscal deficit. It follows that the regime is nonRicardian. In other words, there is empirical evidence in favor of fiscal dominance (the fiscal theory of the price level).

Leeper model also indicates a fiscal dominance regime. We find evidence that the Brazilian economy operates in Region II, i.e., the monetary and fiscal policies are passive and active, respectively. This finding is consistent with the estimation 
of the IS curve, which reveals a significant fiscal deficit.

\section{References}

Almeida, C. L., Peres, M. A., Souza, G. S., \& Taback, B. M. (2003). Optimal monetary rules: The case of Brazil. Applied Economics Letteres, 10(5):299-302.

Benigno, P. \& Woodford, M. (2006). Optimal inflation targeting under alternative fiscal regimes. NBER Working Paper 12158, April.

Blanchard, O. (2004). Fiscal dominance and inflation targeting: Lessons from Brazil. NBER Working Paper 10389, March.

Canzonery, M., Cumby, R., \& Diba, B. (2001). Is the price level determined by the needs of fiscal solvency? American Economic Review, 91(5):1221-1238.

Carneiro, D. D. \& Wu, T. Y. H. (2002). Juros e câmbio: Haverá combinações de instrumentos menos desgastantes para as metas de inflação? Economia Aplicada - Brazilian Journal of Applied Economics, 6(1).

Cochrane, J. H. (1998). A frictionless view of the US inflation. NBER Working Paper 6646.

Cochrane, J. H. (2001a). Long term debt and optimal policy in the fiscal theory of the price level. Econometrica, 69(1).

Cochrane, J. H. (2001b). Money and stock. Mimeo.

Fialho, M. M. \& Portugal, M. S. (2005). Monetary and fiscal policy interactions in Brazil: An application of the fiscal theory of the price level. Pesquisa $e$ Planejamento Econômico, 35(2):657-685.

Freitas, P. S. \& Muinhos, M. K. (2002). A simple model for inflation targeting in Brazil. Brazilian journal of Applied Economics, 6(1).

Gonçalves, C. E. S. (2005). Herança maldita e política monetária em um modelo de assimetria de informação. Revista Brasileira de Economia, 59(4).

Krolzig, M. (1997). Markov Switching Vector Autoregressions. Modeling, Statistical Inference and Application to Business Cycle Analysis. Springer, Berlin.

Leeper, E. M. (1991). Equilibria under 'active' and 'passive' monetary and fiscal policies. Journal of Monetary Economics, 27:129-147.

Leeper, E. M. (2005). A simple model of the fiscal theory of the price level. Indiana University and NBER, May. 
Lima, A. M. C. \& Issler, J. V. (2003). A hipótese das expectativas na estrutura a termo de juros no Brasil: Uma aplicação de modelos de valor presente. Revista Brasileira de Economia, 57(4).

Loyo, E. (1999). Tight money paradox on the loose: A fiscalist hyperinflation. JFK School of Government, Harvard University, Mimeo, June.

Martins, M. A. C. (1980). A nominal theory of the nominal rate of interest and the price level. The Journal of Political Economy, 88(1):174-185.

Morais, J. F. M. \& Andrade, J. P. (2004). Como a dívida pública afeta a política monetária ótima? Finanças Públicas - IX Prêmio Tesouro Nacional.

Muscatelli, V., Tirelli, A., \& Trecroci, C. (2002). Monetary and fiscal policy interacions over the cycle: Some empirical evidence. Manuscript.

Rocha, F. \& Silva, E. P. (2004). Teoria fiscal do nível de preços: Um teste para a economia brasileira no período 1996-2000. Pesquisa e Planejamento Econômico - PPP, 34(3).

Sala, L. (2004). The fiscal theory of the price level: Identifying restrictions and empirical evidence. IGIER - Innocenzo Gasparini Institute for Economic Research, Working Paper 257, April.

Sargent, T. J. (1986). Reaganomics and Credibility, Rational Expectations and Inflation. Harper and Row, New York, NY.

Sargent, T. J. \& Wallace, N. (1975). Rational expectations, the optimal monetary instrument and optimal money supply rule. Journal of Political Economy, $83: 241-254$.

Sargent, T. J. \& Wallace, N. (1981). Some unpleasant monetrist arithmetic. Federal Bank of Minneapolis Quarterly Review, 5(3).

Sidrausky, M. (1967). Rational choice and patterns of growth in a monetary economy. American Economic Review Papers and Proceedings, 57(2).

Sims, C. A. (1994). A simple model for study of the price level and the interaction of monetary and fiscal policy. Economic Theory, 4.

Sims, C. A. (2005). Limits to inflation targeting. In Bernanke, B. S. \& Woodfor, M., editors, The Inflation Targeting Debate. University of Chicago Press, Chicago.

Tanner, E. \& Ramos, A. M. (2003). Fiscal sustainability and monetary versus fiscal dominance: Evidence from Brazil, 1991-2000. Applied Economics, 35(7):859873. 
Taylor, J. B. (1993). Discretion versus policy rules in practice. Carnegie-Rochester Conferences on Public Policy, 39:95-214.

Verdini, M. (2003). Regras monetárias e restrição fiscal: Uma análise da política de metas para a inflação no Brasil. Master's thesis, Escola de Pós-Graduação de Economia da Fundação Getulio Vargas - EPGE/FGV, Rio de Janeiro.

Walsh, C. (2003). Theory and Policy. The MIT Press, 2nd edition.

Woodford, M. (1994). Monetary policy and price-level determinacy in a cash-inadvance economy. Econometric Theory, 4.

Woodford, M. (1995). Price level determinacy without control of a monetary aggregate. NBER Working Paper 5204.

Woodford, M. (1997). Control of the public debt: A requirement for price stability? In Calvo, G. \& King, M., editors, The Debt Burden and Monetary Policy. Macmillian, London.

Woodford, M. (2001). Fiscal requirements for price stability. Journal of Money, Credit and Banking, 33.

Woodford, M. (2003). Interest and Prices. Princeton University Press. 